\title{
TURBIDITY AND QUANTITY OF SEDIMENT PARTICLES DURING THE REGENERATION OF CHEMICAL SOLUTIONS AFTER CLEANING OF BREWING EQUIPMENT IN THE CIP SYSTEM
}

\section{Joanna Piepiórka-Stepuk}

Division of Food Industry Processes and Facilities, Department of Mechanical Engineering, Koszalin University of Technology, Poland

Corresponding author:e-mail: joanna.piepiorka@tu.koszalin.pl

\begin{tabular}{|c|c|}
\hline ARTICLE INFO & ABSTRACT \\
\hline $\begin{array}{l}\text { Article history: } \\
\text { Received: June } 2018 \\
\text { Received in the revised form: } \\
\text { August } 2018 \\
\text { Accepted: September } 2018\end{array}$ & \multirow{2}{*}{$\begin{array}{l}\text { The paper presents results of analysis of turbidity changes in washing } \\
\text { solutions and the quantity of solid particles present in them during } \\
\text { regeneration under various temperature conditions. Three solutions } \\
\text { taken from breweries after the process of washing brewhouse equip- } \\
\text { ment in the CIP system were evaluated. The results were subjected to } \\
\text { statistical analysis, to define the functions that characterize the chang- } \\
\text { es of the tested parameters in relation to time and temperature. The } \\
\text { results showed that the tested solutions have different favourable } \\
\text { conditions for their regeneration. It has also been shown that the } \\
\text { character of changes in solutions in the regeneration process is more } \\
\text { advantageously determined on the basis of turbidity tests of solutions. }\end{array}$} \\
\hline $\begin{array}{l}\text { Key words: } \\
\text { CIP system, } \\
\text { breweries, } \\
\text { brewhouse, } \\
\text { washing solutions, } \\
\text { regeneration, } \\
\text { sedimentation }\end{array}$ & \\
\hline
\end{tabular}

\section{Introduction}

Multiple and long-term use of chemical cleaning solutions in the CIP system requires their continuous regeneration and quality control prior to reuse. After each use, the solutions returned to the tanks of CIP station, are purified from solid deposits and topped up to a specified volume. The concentrations of chemical substances contained in them are also supplemented (Merin et al., 2002). The quality of regenerated solutions is determined by measuring of $\mathrm{pH}$, conductance and concentration. The microbiological purity of solutions is also determined as a limiting condition for their further use (Chung and Lai, 2008).

Solid filtration (MF) and centrifugation techniques are effective methods for purifying solid deposits (Kaya et al., 2009; Judd and Hillis, 2001; Räsänen et al., 2002; GésanGuiziou et al., 2002). Many authors have shown that both methods of regeneration maintain the primary chemical activity of cleaning solutions, as expressed by surface tension (Alvarez et al., 2007; Merin et al., 2002) and allow reducing the amount of sewage discharged into the environment (Dresch et al., 1999; Olajire, 2012; Chen et al., 2012; Blel et al., 2015). Due to the necessity of equipping the CIP cleaning station with a filtration system, as well as to high operating costs related to energy consumption and the need to more fre- 
quent regeneration of filtration membranes in plants, treating of solutions is carried out by sedimentation (Simate et al., 2011; Gönder et al., 2010; Dif et al., 2013).

The process of regeneration of solutions by sedimentation after their use in the cleaning process is based on the natural, automatic precipitation of solid sediment particles eluted from the production installation. It takes place in the CIP station tanks between successive cleaning processes. The kinetics of the sedimentation process depends on the mass and density of precipitates and on the density and viscosity of the solvent - the cleaning solution. The process is often accompanied by coagulation and flocculation of solid deposits (Dif et al., 2013). The temperature of cleaning solutions is of great importance in this process. It has been shown that as the temperature of the $\mathrm{NaOH}$ sodium hydroxide solution increases after cleaning the mash filter, the degree of its purification after 12 hours of sedimentation is different for various temperature values (Piepiórka-Stepuk, 2018). This is due to the change in the density of solutions and sediments that are suspended in them. In addition, it was observed that the sediment particles impact each other at higher temperatures, mixing intensively and spontaneously, which results in a longer solution regeneration time. The above observations were based on measurements of the quantity of particles in solutions with the Shadow Sizing method. The purity of the solution can also be determined by measuring its turbidity (Klahre et al., 2000, Goode et al., 2010). The paper attempts to compare these two criteria for assessing the purity of solutions. For both of these parameters, kinetics of changes in function of temperature and time of the regeneration process of cleaning solutions after their use were presented.

\section{The purpose and scope of research}

The main objective of the research was to determine the function of turbidity changes (M) and the quantity of solid particles (C) in the chemical cleaning solutions, which occur during sedimentation $(t)$ under different temperature conditions $(T)$. The functions will be used to model the process of regeneration of cleaning solutions and to determine their stability during storage in CIP station tanks. The intermediate objective was to indicate favorable conditions for the purification of solutions from sediments by means of sedimentation.

\section{Research methodology}

\section{Research material}

The research material consisted of two solutions of sodium hydroxide $(\mathrm{NaOH}(\mathrm{F})$ and $\mathrm{NaOH}(\mathrm{T}))$ and a solution of a mixture of phosphoric and nitric acids $\left(\mathrm{H}_{3} \mathrm{PO}_{4}+\mathrm{HNO}_{3}\right)$ in a 1:1 ratio. The solutions were used to clean the brewing equipment and apparatus in accordance with the programs presented in Table 1.

The solutions, approx. 2 liters, were sampled three times from the factory CIP tanks after the cleaning process (with sediments) and subjected to a sedimentation process in the temperature range $20-80^{\circ} \mathrm{C}$ (for $\mathrm{NaOH}$ solution) and $20-60^{\circ} \mathrm{C}$ (for the acid solution). During sedimentation, the temperature was increased by $10^{\circ} \mathrm{C}$. The sedimentation was carried out in $1000 \mathrm{ml}$ Imhoff funnels for 12 hours. In order to obtain variable thermal conditions, the funnels were submerged in a water bath and kept there for the entire duration of the tests. The tests were started when the temperature of the solutions stabilized at the determined 
Turbidity and quantity ...

level. In order to determine the process kinetics, approx. $20 \mathrm{ml}$ of each solution were taken during sedimentation. The solutions were tested for changes in their turbidity over time and changes in the quantity of solid matter remaining in them. Readings were made after 1., 2 ., 4., 6. and 12. hour of sedimentation. The sampling site was fixed at a constant height $(5 \mathrm{~cm}$ below the surface of the solution). The blank samples were solutions evaluated before the sedimentation process.

Table 1.

Equipment cleaning programs carried out in breweries

\begin{tabular}{|c|c|c|c|c|c|}
\hline $\begin{array}{l}\text { Cleaning } \\
\text { procedure }\end{array}$ & No. & Stage & $\begin{array}{c}\text { Cleaning agent } \\
(\%)\end{array}$ & $\begin{array}{l}\text { Time } \\
(\min )\end{array}$ & $\begin{array}{l}\text { Temperature } \\
\left({ }^{\circ} \mathrm{C}\right)\end{array}$ \\
\hline \multirow{5}{*}{$\begin{array}{l}\text { Mash tun; } \\
\text { Tank } \\
\text { Boiling pan; } \\
\text { Boiler; } \\
\text { Hop tanks } \\
\text { intermediary; } \\
\text { Sediment } \\
\text { tanks }\end{array}$} & 1. & Pre-rinsing & Water & 5 & Ambient \\
\hline & 2. & $\begin{array}{l}\text { Alkaline } \\
\text { cleaning }\end{array}$ & $\begin{array}{l}\text { Sodium hydroxide solution } \\
\qquad(3 \%) \mathrm{NaOH}(\mathrm{T})\end{array}$ & 110 & $75-80$ \\
\hline & 3. & $\begin{array}{l}\text { Intermediate } \\
\text { rinsing }\end{array}$ & Water & 15 & Ambient \\
\hline & 4. & Acid cleaning & $\begin{array}{l}\text { Acid solution }(1.5 \%) \\
\quad\left(\mathrm{H}_{3} \mathrm{PO}_{4}+\mathrm{HNO}_{3}\right)\end{array}$ & 30 & Ambient \\
\hline & 5. & Final rinsing & Water & 15 & Ambient \\
\hline \multirow{6}{*}{$\begin{array}{l}\text { Wort canal } \\
\text { (pipelines } \\
\text { and the heat } \\
\text { exchanger) }\end{array}$} & 1. & Pre- rinsing & Water & 8 & Ambient \\
\hline & 2. & $\begin{array}{l}\text { Alkaline } \\
\text { cleaning }\end{array}$ & $\begin{array}{c}\text { Sodium hydroxide solution } \\
\qquad(3 \%) \mathrm{NaOH}(\mathrm{T})\end{array}$ & 45 & $75-80$ \\
\hline & 3. & $\begin{array}{l}\text { Intermediate } \\
\text { rinsing }\end{array}$ & Water & 5 & Ambient \\
\hline & 4. & $\begin{array}{l}\text { Acid } \\
\text { cleaning }\end{array}$ & $\begin{array}{l}\text { Acid solution }(1.5 \%) \\
\left(\mathrm{H}_{3} \mathrm{PO}_{4}+\mathrm{HNO}_{3}\right)\end{array}$ & 15 & Ambient \\
\hline & 5. & $\begin{array}{l}\text { Intermediate } \\
\text { rinsing }\end{array}$ & Water & 5 & Ambient \\
\hline & 6. & Disinfection & Peracetic acid & 5 & Ambient \\
\hline \multirow{3}{*}{$\begin{array}{l}\text { Mash } \\
\text { filter }\end{array}$} & 1. & Pre- rinsing & Water & $60 \times 2$ & Ambient \\
\hline & 2. & $\begin{array}{l}\text { Alkaline } \\
\text { cleaning }\end{array}$ & $\begin{array}{l}\text { Sodium hydroxide solution } \\
\qquad(3.5 \%) \mathrm{NaOH}(\mathrm{T})\end{array}$ & 180 & $75-80$ \\
\hline & 3. & Final rinsing & Water & 30 & Ambient \\
\hline
\end{tabular}

\section{Particle quantity measurement}

The test was conducted based on the Shadow Sizing method on the DynamicStudio platform in accordance with the method presented in Piepiórka-Stepuk $(2013,2018)$ and Jakubowski (2016). The tests were carried out after cooling of the solutions. The total vol- 
ume of the evaluated sample resulted from the cuvette volume and was $1.4 \mathrm{ml}$. The exposure area of a single sample was $0.1875 \mathrm{~cm}^{2}$, indicating that the measuring volume of the test solution was approximately $0.05 \mathrm{ml}$ (cuvette thickness $-1 \mathrm{~mm}$ ). The test was carried out in six replications, with 15 images each at a recording frequency of $1 \mathrm{~Hz}$ (frame per second). In this way, a series of 90 images was obtained and analyzed.

\section{Turbidity measurement}

Turbidity measurements were made with a Lovibond TB 300 IR turbidimeter in scattered light at wavelength $\lambda=860 \mathrm{~nm}$ (infrared light) at an angle of $90^{\circ}$. The principle of the method, according to EN-ISO 7027, consisted in absorption of radiation when the light beam passed through the dispersion system. For this purpose, the cuvette with the solution was placed in the measuring cell and subjected to determination. Before each test cycle started, the sensor was calibrated to formazin in the range of 0-1100 NTU (Goode, 2012). The tests of samples collected during sedimentation were carried out in 4 replicates. Thus, a series of 12 measurements was obtained for each point in the test plan.

\section{Statistical analysis}

The obtained results were averaged and summarized in the form of final turbidity and the number of particles in the volume of the analyzed solutions after 12 hours of sedimentation. For the obtained results, standard deviations of dispersion were obtained in relation to the mean values. To check the significance of the influence of temperature on the final solution purity, a Fisher-Snedecor test was carried out in the Statistica 13.1 program, to check the zero hypothesis $\mathrm{H}_{0}:\left(\mu=\mu_{0}\right)$ and alternative $\mathrm{H}_{1}:\left(\mu \neq \mu_{0}\right)$, where $\mathrm{F}_{\text {crit }}$ for the quantity of particles and $\mathrm{F}_{\text {crit }}$ for turbidity were calculated for each solution and presented in the results. A HSD Tukey post hoc test was also carried out at the significance level $\alpha=0.05$. Based on the dispersion curves, the nature of the influence of individual independent variables (time $-t$ and temperature $-T$ ) on the turbidity $(M)$ and the quantity of particles $(C)$ changing during sedimentation were determined. The determined curves constituted the basis for accepting partial functions of the relationship between independent variables $(t, T)$ and dependent variables $(M, C)$. Modeling of the functions $M=f(t) ; M=f(T) ; C=f(t)$ and $\mathrm{C}=\mathrm{f}(\mathrm{T})$ and their alignment was performed with the iterative least squares procedures estimation method, using the Gauss-Newton algorithm. The adequacy of the adopted model was verified by the goodness of fit of the predicted values to the observed ones.

\section{Research methodology}

The final turbidity of the tested solutions (M) and the quantity of solid sediments remaining in the solution $(\mathrm{C})$ after the sedimentation process, under various temperature conditions are shown in Figure 1. 
Turbidity and quantity ...
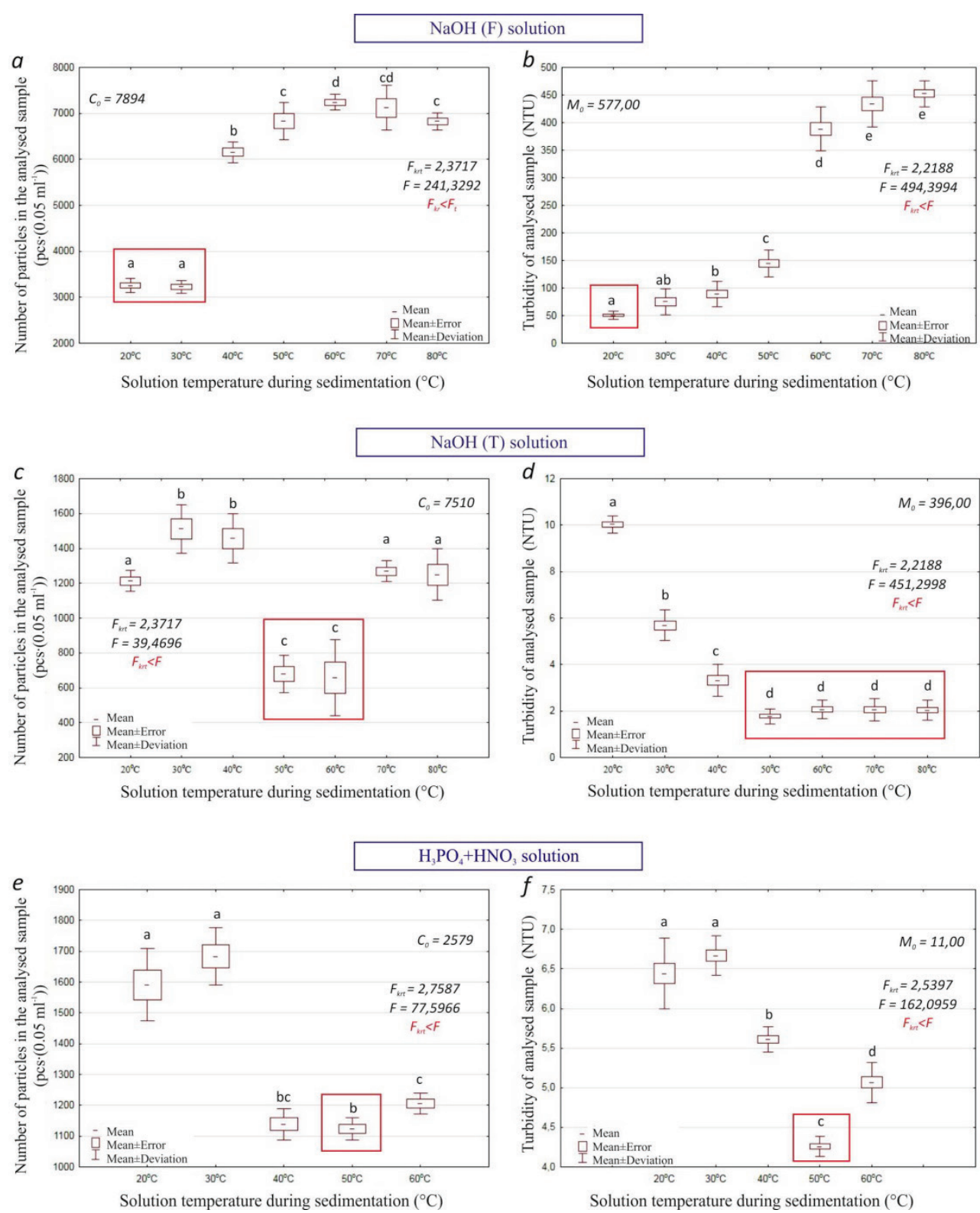

Figure 1. Dispersion of the quantity of solid sediments remaining in washing solutions after 12 hours of sedimentation under various temperature conditions and their final turbidity: $a, b-\mathrm{NaOH}(F)$ sodium hydroxide solution; $c, d$ - sodium hydroxide solution $\mathrm{NaOH}(F)$; e, $f$-a solution of a mixture of phosphoric and nitric acids $\left(\mathrm{H}_{3} \mathrm{PO}_{4}+\mathrm{HNO}_{3}\right)$ 
The Fisher test result for the analyzed experimental results allowed to reject the zero hypothesis $\mathrm{H}_{0}:\left(\mu=\mu_{0}\right)$ regarding the equality of the mean number of particles and turbidity of the solutions after the sedimentation process under various conditions, and to adopt the alternative hypothesis $\mathrm{H}_{1}:\left(\mu \neq \mu_{0}\right)$, where the measured values for both the $\mathrm{F}$ statistic satisfy the inequality $\left(F_{\text {crit }}<F\right)$ (Fig. 1). The obtained results indicate a significant impact of the temperature of the solutions during sedimentation on their final turbidity and the quantity of the remaining solid sediments.

It has been observed that the sedimentation of particles in the $\mathrm{NaOH}(\mathrm{F})$ sodium hydroxide solution after cleaning the mash filter is favored by the temperature $20-30^{\circ} \mathrm{C}$ (Fig. 1a). After the completion of the sedimentation process, the smallest quantity of solid particles for these conditions was observed, approx. 3,200 (pcs. $\cdot 0.05 \mathrm{ml}^{-1}$ ), which, however, still accounts for approx. $40 \%$ of the initial contamination $\left(C_{0}=7894 \mathrm{pcs} \cdot \cdot 0.05 \mathrm{ml}^{-1}\right)$. The lowest turbidity of this solution was obtained after the sedimentation process in the temperature range $20-40^{\circ} \mathrm{C}$ (Fig. 1b), the turbidity of the solution after sedimentation at $20^{\circ} \mathrm{C}$ is significantly different from the turbidity of the solution after sedimentation at $40^{\circ} \mathrm{C}$ (Fig. 1b). For these conditions, the turbidity of the solution in relation to the initial value decreased by about $85 \%$. A significant increase in turbidity was observed only at $50^{\circ} \mathrm{C}(145$ NTU). Further test results indicate that the higher the temperature of $\mathrm{NaOH}(\mathrm{F})$ solution during sedimentation, the less favorable conditions for the regeneration of this solution. Ultimately, in the temperature range of $60-80^{\circ} \mathrm{C}$, both the turbidity of sodium hydroxide and the quantity of sediments found in it decreased to a small extent, in comparison to the initial sample.

The different nature of temperature impacts on sediment deposition was observed in the $\mathrm{NaOH}$ (T) sodium hydroxide solution. This solution was used in the brewery to clean tanks in the brewhouse, the heat exchanger and pipelines transporting the wort. The smallest quantity of particles in this solution after sedimentation was recorded at temperatures 50 and $60^{\circ} \mathrm{C}\left(679 \mathrm{pcs} \cdot \cdot 0.05 \mathrm{ml}^{-1}\right.$ and $657 \mathrm{pcs} \cdot \cdot 0.05 \mathrm{ml}^{-1}$, respectively) (Fig. 1c). This represented $9 \%$ of the initial contamination. The quantity of particles remaining in the sodium hydroxide solution increased in temperatures above and below the level. The reason may be changes in the density and viscosity of the solution causing, first of all, an increase in the resistance of the medium in which sediment particles are suspended and of the time of their gravitational subsidence. On the other hand, the reason may be the increase of internal energy of the medium and activation of Brownian motion causing intense and spontaneous mixing of sediment particles in the solution (Piepiórka-Stepuk, 2018; Dif et al., 2013). Similar results were obtained in the case of final turbidity measurement of $\mathrm{NaOH}(\mathrm{Na})$ sodium hydroxide solution after 12 hours of precipitate sedimentation. The lowest turbidity of the solution (about $2 \mathrm{NTU}$ ) was obtained after sedimentation at $50^{\circ} \mathrm{C}$, which in turn contributed to $99 \%$ regeneration of the solution. The higher temperature of $\mathrm{NaOH}(\mathrm{T})$ solution (up to $80^{\circ} \mathrm{C}$ ) during its regeneration did not significantly impact the change in its final turbidity (Tukey's test) (Fig. 1d). In the case of this solution, it was observed that in general a good regeneration effect was obtained under all temperature conditions. With regard to the initial sample $\left(\mathrm{C}_{0}=7510 \mathrm{pcs} \cdot \cdot 0.05 \mathrm{ml}^{-1} ; \mathrm{M}_{0}=396 \mathrm{NTU}\right)$, the regeneration efficiency evaluated based on the quantity of particles in the solution after 12 hours of sedimentation under the least favorable conditions $\left(30^{\circ} \mathrm{C}\right)$ decreased to $80 \%$, and based on turbidity measurement - up to $97 \%\left(20^{\circ} \mathrm{C}\right)$. 
Turbidity and quantity ...

Test of sedimentation in the acidic cleaning solution $\left(\mathrm{H}_{3} \mathrm{PO}_{4}+\mathrm{HNO}_{3}\right)$ showed that this process is most effective at $50^{\circ} \mathrm{C}$. The least quantity of solid particles (approx. 1130 pcs. $\cdot 0.05 \mathrm{ml}^{-1}$ ) was recorded after 12 hours of sedimentation under these temperature conditions (Fig. 1e). Similarly, the lowest turbidity of the solution, at the level of 4 NTU (Fig. 1f), was also obtained during sedimentation at $50^{\circ} \mathrm{C}$. Based on the analysis of both parameters and with regard to the initial contamination of this solution $\left(\mathrm{C}_{0}=2579 \mathrm{pcs} \cdot 0.05 \mathrm{ml}^{-1}\right.$, $\mathrm{M}_{0}=11 \mathrm{NTU}$ ), it can be concluded that at $50^{\circ} \mathrm{C}$ the acidic washing solution is self-cleaning in approx. $60 \%$. The remaining part of the sediment is a suspension. The results obtained are in line with the results of Dif et al. (2013), who observed variable effects of temperature in the process of regeneration of cleaning solutions.
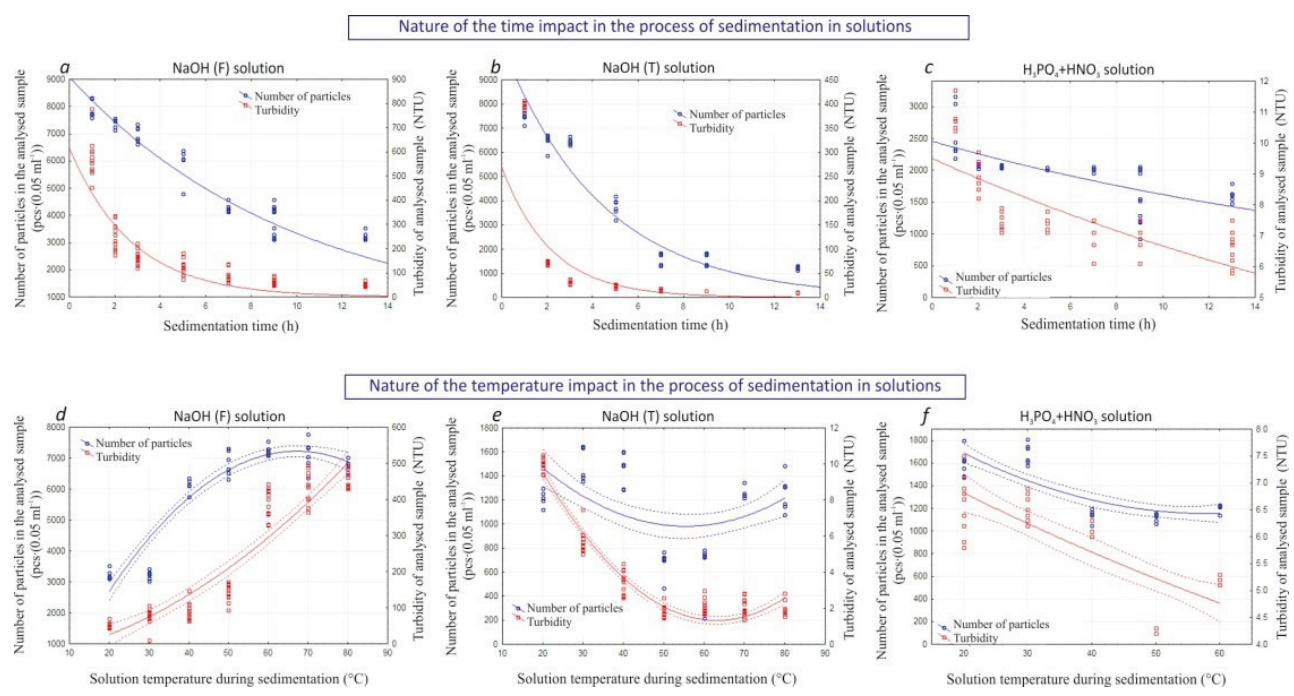

Figure 2. Approximation functions in comparison with the distribution of test results with respect to: $a, b, c$-sedimentation time (exponential distribution) and $d, e, f$-temperature of solutions during sedimentation (polynomial)

Further analyzes were aimed at determining the nature of the impact of time and temperature on the quantity of sediments remaining in the solutions, and their final turbidity. The resulting distribution suggested that the impact of time on the degree of regeneration of solutions, as expressed by the quantity of solid particles remaining in them and its turbidity, is preferably approximated with the exponential function (Fig. 2a, b, c), whereas the temperature impact - with a second degree polynomial (Fig. 2d, e, f). This is in line with previous research carried out in this area (Piepiórka-Stepuk, 2018). Following the obtained distribution against the dependent variables analyzed, the following partial dependence functions were determined: $M=f(t) ; M=f(T) ; C=f(t)$ and $C=f(T)$. Forms of obtained functions are presented in Figures 3 and 4, along with correlation coefficients determining the degree of their fit to empirical data.

The obtained results indicate that the regeneration time differs per solution (Fig. 3). The minimum time for regeneration of $\mathrm{NaOH}(\mathrm{T})$ sodium hydroxide solution and the acid mix- 
ture solution $\left(\mathrm{H}_{3} \mathrm{PO}_{4}+\mathrm{HNO}_{3}\right)$ for the adopted test conditions was from 4 to 6 hours (Fig. $3 \mathrm{c}, \mathrm{d}, \mathrm{e}, \mathrm{f})$. Both solutions were used to clean tanks and the so-called wort canal. On the other hand, the regeneration of $\mathrm{NaOH}(\mathrm{F})$ sodium hydroxide solution took place within a slightly longer time, ranging from 6 to 8 hours for the adopted test conditions (Fig. 3a, b).
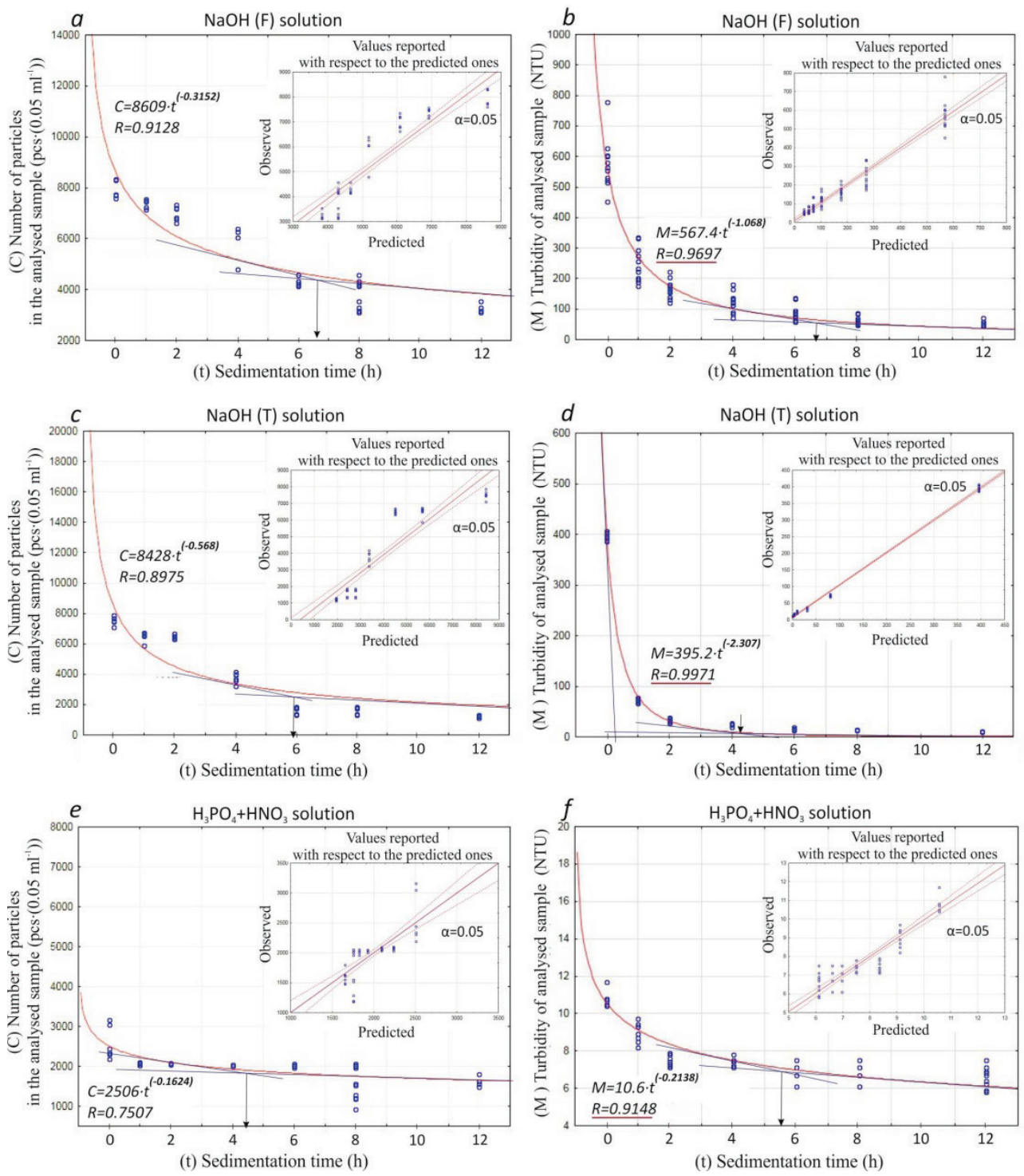

Figure 3. Distribution of functions demonstrating changes in the quantity of solid particles in washing solutions $(a, c, e)$ and their turbidity $(b, d, f)$ during sedimentation 
Turbidity and quantity ...

The solution regeneration time, determined based on the distribution of functions, is consistent both in terms of the turbidity curves and the quantity of solid sediment particles that constitute the suspension. It was only observed that the determination coefficients for the models of the function of turbidity change during the sedimentation time $M=f(t)$ indicate a better fit to the empirical data than for the $\mathrm{C}=\mathrm{f}(\mathrm{t})$ function.
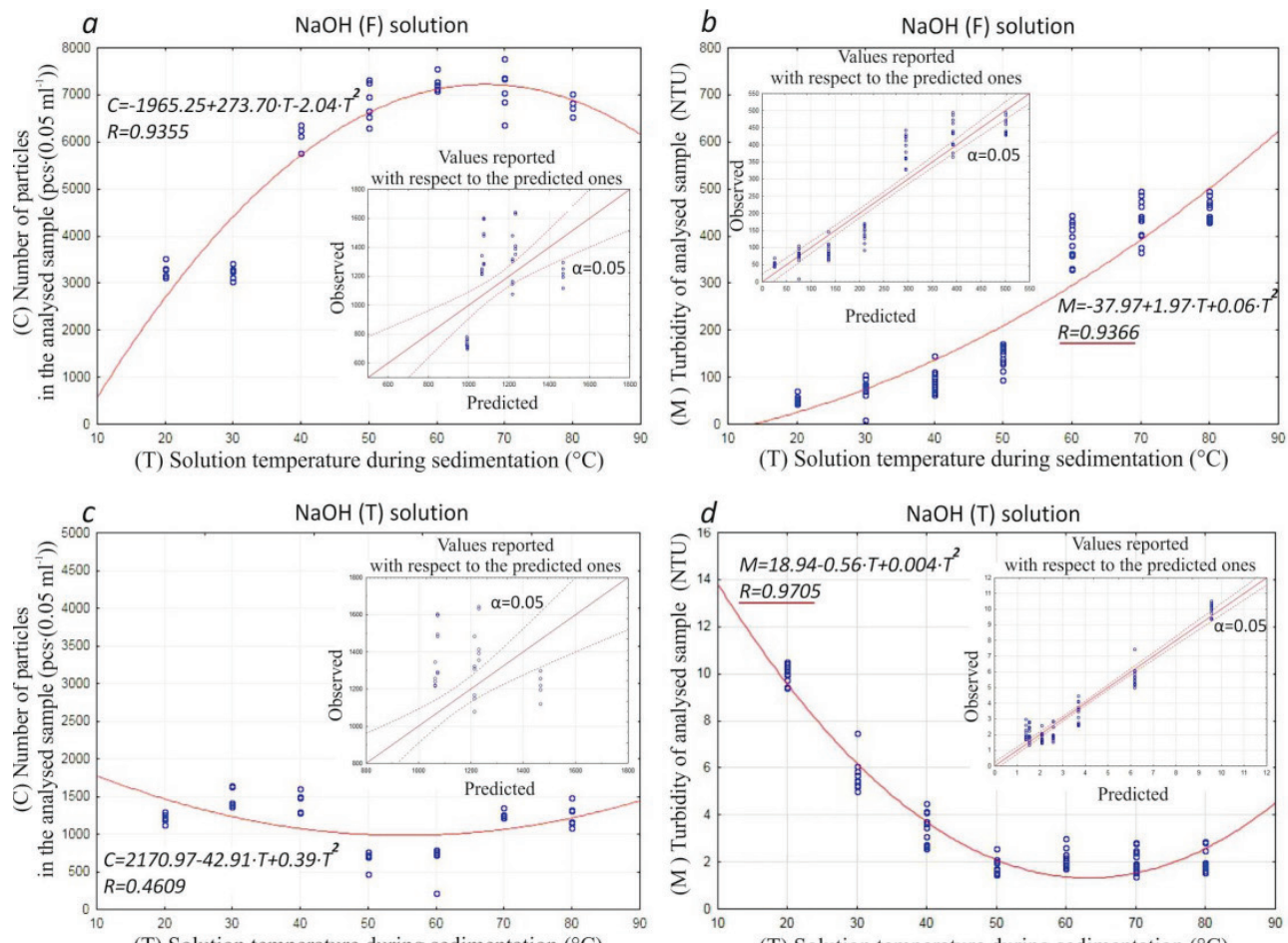

(T) Solution temperature during sedimentation $\left({ }^{\circ} \mathrm{C}\right)$

(T) Solution temperature during sedimentation $\left({ }^{\circ} \mathrm{C}\right)$
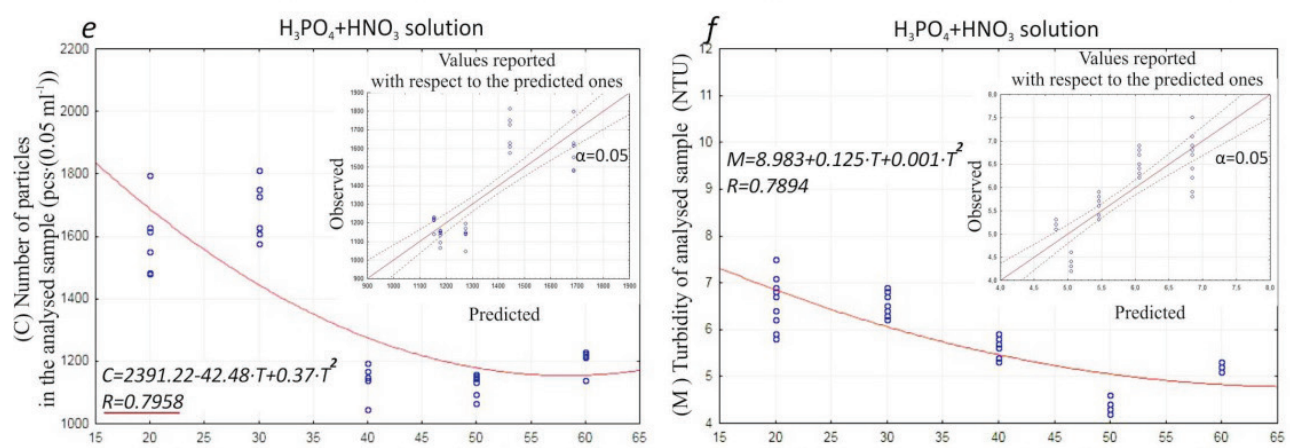

(T) Solution temperature during sedimentation $\left({ }^{\circ} \mathrm{C}\right)$

(T) Solution temperature during sedimentation $\left({ }^{\circ} \mathrm{C}\right)$

Figure 4. Distribution of functions demonstrating changes in the quantity of solid particles in washing solutions $(a, c, e)$, and their turbidity $(b, d, f)$ depending on temperature 
Based on the obtained distribution of the functions demonstrating the presence of solid sediments in the solutions $C=f(T)$, and of the final turbidity of the solutions $M=f(T)$, function extremes determining the temperature values at which the process of solution regeneration is least or most preferable were determined. Based on the turbidity change function determined for the $\mathrm{NaOH}(\mathrm{F})$ sodium hydroxide solution, it was found that the most favorable temperature conditions for the regeneration of this solution are in the temperature range $20-30^{\circ} \mathrm{C}$ (Fig. $4 \mathrm{~b}$ ). In the case of this solution, the function of changes in the quantity of solid particles allowed to additionally determine unfavorable regeneration conditions that occur in the temperature range of $60-70^{\circ} \mathrm{C}$ (Fig. 4a). Favorable conditions for the regeneration of the remaining test solutions occur in the temperature range $50-60^{\circ} \mathrm{C}$ (Fig. 4c, d, e, f). The preferred temperature for regeneration of the solutions, determined on the basis of the function distributions, is in agreement both with their turbidity curves and the quantity of solid sediment particles remaining in them. At the same time, as in the case of the time function distributions, it was observed that the correlation coefficients for the designated turbidity change functions $\mathrm{M}=\mathrm{f}(\mathrm{t})$ indicate a better fit to empirical data than that of functions describing the quantity of particles remaining in solutions $\mathrm{C}=\mathrm{f}(\mathrm{t})$.

\section{Conclusions}

1. The time and temperature at which sedimentation is carried out affect in a non-linear way the final turbidity of solutions used to clean the brewhouse equipment, and the presence of solid sediment particles in them. The nature of changes in turbidity of the solutions and the quantity of sediment particles remaining in them during sedimentation is best reflected by a negative exponential function. On the other hand, the nature of temperature impact on changes in the analyzed parameters is best reflected by a second degree polynomial, where the extreme of functions indicates the most or the least favorable conditions for the regeneration process of cleaning solutions.

2. Based on the determined functions, it is possible to predict changes in turbidity and the quantity of sediment particles present in solutions during sedimentation, and for different temperature values. The obtained distributions of both analyzed measurements are characterized by similar changes, where for the functions determining the change of turbidity $\mathrm{M}=\mathrm{f}(\mathrm{t})$ and $\mathrm{M}=\mathrm{f}(\mathrm{T})$ higher correlation coefficients were obtained. This indicates a better fit to empirical data than in the case of $\mathrm{C}=\mathrm{f}(\mathrm{t})$ and $\mathrm{C}=\mathrm{f}(\mathrm{T})$. In addition, measuring solution turbidity is methodically simpler and faster to execute. Therefore, further research and analysis aimed at determining the original criteria for the model of optimization of conditions, in which cleaning solutions used for cleaning brewhouse equipment are regenerated should focus only on the analysis of turbidity changes of solutions.

3. The determined function models allow determination of favorable conditions for purification of solutions from solid sediments by sedimentation. 
Turbidity and quantity $\ldots$

\section{References}

Alvarez, N., Gésan-Guiziou, G., Daufin, G. (2007). The role of surface tension of re-used $\mathrm{NaOH}$ on the washing efficiency in dairy plants, International of Dairy Journal, 17, 403-411.

Blel, W., Dif, M., Sire, O. (2015). Effect of a new regeneration process by adsorption-coagulation and flocculation on the physicochemical properties and the detergent efficiency of regenerated washing solutions. Journal of Environmental Management, 155, 1-10.

Chen, L., Chen, R., Yin, H., Sui, J., Lin, H. (2012). Cleaning in place with onsite-generated electrolysed oxidizing water for water-saving disinfection in breweries. Journal of the Institute of Brewing, 118(4), 401-405.

Chung, S.L., Lai, Y.H. (2008). Process control of brewery plants. Journal of the Chinese Institute of Engineers, 31(1), 127-140.

Dif, M., Blel, W., Tastayre, G., Lendormi, T., Sire, O. (2013). Identification of transfer mechanisms involved in soiled CIP solutions regeneration at extreme $\mathrm{pH}$ and high temperature. Journal of Food Engineering, 114, 477-485.

Dynamic Studio 4.1. (2015). Software User's Guide. Dantec Dynamics A/S. Publication no.: 9040U1858

DynamicStudio Shadow Sizer. (2011). For a Wide Range of Sizer Applications. Product Information Publication no.: pi 235 v8. Dantec Dynamics A/S.

Gésan-Guiziou, G., Alvarez, N., Jacob, D., Daufina, G. (2007). Cleaning-in-place coupled with membrane regeneration for re-using caustic soda solutions. Separation and Purification Technology, 54(3), 329-339.

Gönder, Z.B., Kaya, Y., Vergili, I., Barlas, H. (2010). Optimization of filtration conditions for CIP wastewater treatment by nanofiltration process using Taguchi approach. Separation and Purification Technology, 70(3), 265-273.

Goode, K.R. (2012). Characterizing the cleaning behaviour of brewery foulants. To minimise the cost of Cleaning In Place operations. Doctoral dissertation of University of Birmingham.

Goode, K.R., Asteriadou, K., Fryer, P.J., Picksley, M., Robbins, P.T. (2010). Characterising the cleaning mechanisms of yeast and the implications for Cleaning In Place (CIP). Food and Bioproducts Processing, 88(4), 365-374.

Jakubowski, M., Antonowicz, A., Janowicz, M., Sterczyńska, M., Piepiórka-Stepuk, J., Poreda, A. (2016). An assessment of the potential of shadow sizing analysis and Particle Image Velocimetry (PIV) to characterise hot trub morphology. Journal of Food Engineering, 173, 34-41.

Judd, S.J., Hillis, P. (2001). Optimisation of combined coagulation and microfiltration for water treatment. Water Research 35(12), 2895-2904.

Kaya, Y., Barlas, H., Arayici, S. (2009). Nanofiltration of Cleaning-in-Place (CIP) wastewater in a detergent plant: effects of $\mathrm{pH}$, temperature and transmembrane pressure on flux behavior. Separation and Purification Technology, 65(2), 117-129.

Klahre, J., Flemming, M., Flemming, H-C. (2000). Monitoring of biofouling in papermill process waters. Water Research, 34, 3657-3665.

Merin, U., Gésan-Guiziou, G., Boyaval, E., Daufin, G. (2002). Cleaning-in-place in the dairy industry: criteria for reuse of caustic $(\mathrm{NaOH})$ solutions. Dairy Science Technology, 82(3), 357-366.

Olajire, A.A. (2012). The brewing industry and environmental challenges. Journal of Cleaner Production. (in press) doi.org/10.1016/j.jclepro.2012.03.003.

Piepiórka-Stepuk J. (2018). Impact of caustic soda solution temperature on efficiency of its cleaning on solid sediments after completed process of cleaning in CIP system of brewing unit. Agricultural Engineering, 22(2), 79-89.

Piepiórka-Stepuk, J., Mierzejewska, S., Kubiak, M.S. (2014). Assessment of contamination of particles occurrence in chemical cleaning solutions stored in tanks of CIP. PAK, 60(10), 889-892. 
Räsänen, E., Nyström, M., Sahlstein, J., Tossavainen, O. (2002). Purification and regeneration of diluted caustic and acidic washing solutions by membrane filtration. Desalination, 149(1-3), 185-190.

Rivera, A., González, J.S., Carrillo, R., Martínez, J.M. (2009). Operational change as a profitable cleaner production tool for a brewery. Journal of Cleaner Production, 17(2), 137-142.

Simate, G.S., Cluett, J., Iyuke, S.E., Musapatika, E.T., Ndlovu, S., Walubita, L.F., Alvarez, A.E. (2011). The treatment of brewery wastewater for reuse: State of the art. Desalination, 273(2-3), 235-247.

\section{METTNOŚĆ I ILOŚĆ CZASTEK OSADÓW W CZASIE REGENERACJI CHEMICZNYCH ROZTWORÓW PO PROCESIE MYCIA URZĄDZEŃ BROWARNICZYCH W SYSTEMIE CIP}

Streszczenie. W pracy zaprezentowano wyniki analiz zmian mętności roztworów myjących oraz ilości obecnych w nich cząstek osadów stałych w czasie regeneracji w różnych warunkach temperaturowych. Ocenie poddano trzy roztwory pobierane $\mathrm{z}$ browarów po procesie mycia urządzeń warzelni w systemie CIP. Wyniki poddano analizie statystycznej wyznaczając funkcje charakteryzujące zmiany badanych parametrów w zależności od czasu i temperatury. Wyniki badań wykazały, że badane roztwory posiadają odmiennie korzystne warunki ich regeneracji. Wykazano również że charakter zachodzących zmian w roztworach w procesie ich regeneracji korzystniej jest określać na podstawie pomiaru mętności roztworów.

Słowa kluczowe: system CIP, browary, warzelnia, roztwory myjące, regeneracja, sedymentacja 